\title{
Peningkatan Hasil Belajar Mengenal Kosakata Tentang Cara Memelihara Kesehatan Menggunakan Media Gambar Siswa Kelas 1A SDN Blitar
}

\author{
Indah Kusmiati ${ }^{(1)}$ \\ ${ }^{1}$ SDN Blitar, Kecamatan Sukorejo, Kota Blitar \\ Email: ${ }^{1}$ indahkusmiati@yahoo.com \\ DOI: https://doi.org/10.28926/riset_konseptual.v2i4.77
}

\begin{abstract}
ABSTRAK
Penelitian ini menggunakan model penelitian tindakan dari Kemmis dan Taggart yang berbentuk spiral dari siklus yang satu ke siklus berikutnya. Setiap siklus melalui tahap perencanaan, pelaksanaan, pengamatan dan refleksi. Tahap pelaksanaan menerapkan lima tahap penerapan media gambar sesuai pendapat ahli. Akhir siklus II diketahui terdapat peningkatan hasil belajar mengenal kosakata tentang cara memelihara kesehatan menggunakan media gambar. Pada siklus I jumlah hasil belajar I pertemuan I sebesar 2180 dan meningkat menjadi 2260 pada pertemuan II sehingga diperoleh rata-rata sebesar 2220. Nilai rata-rata hasil belajar siswa pada pertemuan I sebesar 78 dan meningkat menjadi 81 pada pertemuan II. Rata-rata nilai siswa pada Siklus I sebesar 79. Jumlah siswa yang tuntas pada pertemuan I sebesar $61 \%$ meningkat pada pertemuan II menjadi $75 \%$, dengan rata-rata sebesar 68\%. Sedangkan pada siklus II pertemuan I adalah 2330 dan meningkat menjadi 2390 pada pertemuan II, sehingga diperoleh rata-rata siklus II sebesar 2360. Jumlah siswa tuntas pada pertemuan I sebanyak 23 siswa dan meningkat menjadi 26 siswa pada pertemuan II, atau telah tercapai ketuntasan klasikal sebesar $88 \%$
\end{abstract}

Kata kunci: hasil belajar, kosakata, media gambar

\section{PENDAHULUAN}

Pembelajaran di sekolah dasar seringkali mengalami banyak permasalahan. Permasalahan yang umum terjadi adalah tidak tercapai tujuan pembelajaran. Hal demikian juga terjadi di kelas 1a sdn blitar. Observasi yang dilakukan oleh guru selama bulan juli dan awal agustus 2018 fokus terhadap proses pembelajaran pada muatan bahasa indonesia. Hasil observasi awal dijumpai aktivitas yang terjadi di kelas: (1) guru tidak menggunakan media pengajaran. (2) guru menyampaikan pembelajaran dengan ceramah dan membaca buku bersama. (3) siswa lebih cenderung pasif yang terlihat dari 28 siswa, hanya 14 siswa yang benar-benar mau menyimak penjelasan guru. Siswa yang lain terlihat bergurau dan bosan dengan pembelajaran yang sedang berlangsung, (4) siswa masih malu dan ragu untuk menjawab pertanyaan ataupun mengajukan pendapat.

Menurut mulyasa (dalam yiyin anggarini, 2010:2), guru perlu memperhatikan beberapa hal untuk mendukung siswa mencapai keberhasilan belajar, yaitu (1) mengurangi metode ceramah, (2) bahan harus dimodifikasi dan diperkaya, (3) menggunakan prosedur yang bervariasi, (4) menciptakan situasi belajar yang dapat mengembangkan kemampuan anak untuk bekerja sama, (5) melibatkan siswa dalam berbagai kegiatan.

Permasalahan yang ditemui dalam kegiatan pembelajaran, peneliti memilih alternatif untuk meningkatkan hasil belajar siswa kelas i pada muatan bahasa indonesia kd. 3.5 mengenal kosakata tentang Cara memelihara kesehatan melalui teks pendek (berupa gambar, tulisan, dan slogan sederhana) dan/atau eksplorasi lingkungan. Materi tersebut merupakan materi pada semester ganjil yang terdapat pada kurikulum 2013 untuk kelas i sekolah dasar. 
Vol. 2 No. 4, Oktober 2018;

Upaya peneliti dalam memperbaiki pembelajaran di kelas i adalah dengan menggunakan media gambar. Menurut basuki dan farida (2001:42), mengemukakan kelebihan media gambar, yaitu: (1) umumnya murah harganya, (2) mudah didapat, (3) mudah digunakan, (4) dapat memperjelas suatu masalah, (5) lebih realistis, (6) dapat membantu mengatasi keterbatasan pengamatan, (7) dapat mengatasi keterbatasan ruang.

Sedangkan keterbatasan media gambar adalah (1) semata-mata hanya medium visual, (2) ukuran gambar seringkali kurang tepat untuk pengajaran dalam kelompok besar, (3) memerlukan ketersediaan sumber ketrampilan dan kejelian guru dalam memanfaatkannya.

Berdasarkan pada latar belakang penelitian maka dapat dirumuskan beberapa permasalahan sebagai berikut: 1) Bagaimanakah penggunaan media gambar dapat meningkatkan hasil belajar mengenal kosakata tentang cara memelihara kesehatan siswa kelas 1A SDN Blitar? 2) Bagaimanakah peningkatan hasil belajar mengenal kosakata tentang cara memelihara kesehatan siswa kelas 1A SDN Blitar setelah menggunakan media gambar?

Tujuan penelitian meliputi dua hal yaitu 1) Mendeskripsikan penggunaan media gambar dalam meningkatkan hasil belajar mengenal kosakata tentang cara memelihara kesehatan siswa kelas 1 A SDN Blitar 2) Mendeskripsikan peningkatan hasil belajar mengenal kosakata tentang cara memelihara kesehatan siswa kelas $1 \mathrm{~A}$ SDN Blitar setelah menggunakan media gambar.

\section{METODE \\ Lokasi dan Waktu}

Lokasi: Penelitian ini dilakukan di SDN Blitar Jl. Joko Kandung No. 88 Kecamatan Sukorejo Kota Blitar. Waktu pelaksanaan penelitian yaitu mulai bulan Juli 2018 sampai dengan bulan Oktober 2018, rincian waktu pelaksanaan dan kegiatannya adalah sebagai berikut : a) Siklus I Pertemuan ke-1 dilaksanakan pada hari Senin tanggal 20 Agustus 2018 membahas tema 2 subtema 1 pembelajaran ke-1 b) Siklus I Pertemuan ke-2 dilaksanakan pada hari Selasa tanggal 21 Agustus 2018 membahas tema 2 subtema 1 pembelajaran ke-2 c) Siklus II Pertemuan ke-1 dilaksanakan pada hari Kamis tanggal 23 Agustus 2018 membahas tema 2 subtema 1 pembelajaran ke-3 d) Siklus II Pertemuan ke-2 dilaksanakan pada hari Selasa tanggal 28 Agustus 2018 membahas tema 2 subtema 1 pembelajaran ke-5

\section{Subjek Penelitian}

Subjek pada penelitian ini yaitu kelas $1 \mathrm{~A}$ di SDN Blitar, semester ganjil tahun pelajaran 2018/2019 dengan jumlah 28 anak, yang terdiri dari 13 putra dan 15 putri. Berdasarkan domisili atau tempat tinggal mereka terbagi dalam wilayah kabupaten dan kota. Siswa yang bertempat tinggal di Kota Blitar putra sebanyak 11 orang dan putri sebanyak 12 orang siswanya dari Kabupaten Blitar.

\section{Prosedur Penelitian}

Sesuai dengan jenis penelitian yang dipilih, yaitu penelitian tindakan kelas, maka penelitian ini menggunakan model penelitian tindakan dari Kemmis dan Taggart dalam (Arikunto, 2007: 15), yaitu berbentuk spiral dari siklus yang satu ke siklus berikutnya. Setiap siklus meliputi planning (rencana), action (tindakan), observation (pengamatan), dan reflection (refleksi). Langkah pada siklus berikutnya adalah perencanaan yang sudah direvisi, tindakan, pengamatan, dan refleksi. Sebelum masuk pada siklus 1 dilakukan tindakan pendahuluan yang berupa identifikasi permasalahan.

\section{Siklus I}

Hal-hal yang dilakukan pada tahap perencanaan siklus I adalah 1) memilih materi yang akan dipelajari siswa. 2) merancang RPP menggunakan media gambar, 3) 
menyiapkan lembar tes akhir, 4) menyiapkan lembar observasi aktivitas guru dan siswa. 5) menyiapkan lembar catatan lapangan.

Pelaksanaan tindakan dilaksanakan sesuai dengan rencana pembelajaran yang telah dibuat. Pelaksanaan tindakan yang dilaksanakan merupakan kegiatan dengan menggunakan media gambar .

Kegiatan yang dilakukan oleh guru: 1) guru menyiapkan gambar tentang gerakan yang bisa dilakukan untuk memelihara kesehatan 2) siswa diajak mengamati gambar, 3) siswa menganalisa gambar 4) siswa mencatat hasil diskusi, 5) siswa membacakan hasil diskusi, 6) siswa mendengarkan komentar guru tentang hasil diskusi, 7) evaluasi.

Observasi dilaksanakan selama kegiatan pelaksanaan Siklus I Pertemuan I dan II berlangsung. Pengamatan dilakukan oleh mitra peneliti yang bertindak sebagai observer. Objek yang diamati adalah aktivitas guru dan aktivitas siswa saat pembelajaran. Pengamatan dilakukan sesuai dengan lembar observasi yang telah disiapkan sebelumnya. Hasil observasi dicatat dalam lembar observasi.

Refleksi dilakukan berdasarkan data yang diperoleh, data diolah dan dianalisis. Kekurangan dan kelemahan yang tampak akan diperbaiki pada pertemuan selanjutnya.

\section{Siklus II}

Siklus II dilaksanakan berdasarkan hasil siklus I dengan memperbaiki beberapa permasalahan yang menyebabkan kegiatan pembelajaran kurang berhasil. Siklus II juga melalui tahap perencanaan, pelaksanaan, observasi dan refleksi sebagaimana pada Siklus I

\section{Instrumen Penelitian}

Instrument yang digunakan adalah lembar observasi guru dan siswa, lembar tes, lembar catatan lapangan dan dokumentasi.Setelah data dianalisis kemudian disajikan berupa tabel dan paparan diskripsi. Setelah itu ditarik kesimpulan untuk mencarai kriteria. Kriteria yang digunakan adalah:

$$
\begin{array}{ll}
85 \%<\mathrm{NR} \leq 100 \% & : \text { Sangat baik } \\
70 \%<\mathrm{NR} \leq 84 \% & : \text { Baik } \\
55 \%<\mathrm{NR} \leq 69 \% & : \text { Cukup } \\
45 \%<\mathrm{NR} \leq 54 \% & : \text { Kurang baik } \\
0 \%<\mathrm{NR} \leq 44 \% & : \text { Sangat kurang baik }
\end{array}
$$

\section{Teknik Analisis Data dan Kriteria Keberhasilan}

Teknik analisis data dilakukan setelah melakukan tindakan pada masingmasing siklus yang telah dilakukan. Teknik analisis data yang dilakukan pada penelitian ini adalah teknik analisis data kualitatif yaitu menggambarkan kenyataan atau data sesuai dengan data yang diperoleh dengan tujuan untuk mengetahui peningkatan hasil belajar siswa serta sejauh mana siswa mampu memunculkan sikap rasa tanggung jawab dalam pembelajaran. Untuk mengetahui hasil belajar dengan menggunakan media gambar maka digunakan Kriteria Ketuntasan Minimum (KKM). Data-data yang dianalisis dipaparkan sebagai berikut: 1). Data yang bersumber dari format observasi meliputi a) Data hasil observasi aktivitas guru, dianalisis dengan menguraikan data yang telah dibuat pengamat. Aspek-aspek yang diamati dijelaskan secara cermat dalam lampiran. Caranya skor yang diperoleh dibagi skor total dan dikalikan 100. Apabila hasil yang diperoleh lebih dari $75 \%$ dari skor total, maka guru sudah menerapkan pembelajaran dengan menggunakan media gambar dengan baik. b) Data hasil observasi aktivitas siswa, yaitu dari skor yang diperoleh dibagi jumlah skor keseluruhan dikali 100. Apabila hasil persentase menunjukkan peningkatan pada setiap siklus maka kegiatan yang dilakukan siswa sudah baik. 2) Data yang bersumber dari tes a) Untuk menilai hasil tes, dapat diketahui dari hasil tes yang dicari nilai rataratanya. Untuk peningkatan hasil belajar maka digunakan nilai yang diperoleh siswa 
yang disesuaikan dengan KKM sebagai indikator peningkatan hasil.

b) Untuk ketuntasan belajar, ketuntasan belajar adalah penguasaan penuh yang didapat oleh siswa dalam menguasai materi tertentu secara menyeluruh yang dibuktikan dengan hasil belajar yang baik pada materi tersebut. Siswa disebut tuntas belajar apabila mencapai skor minimal 75 . Kelas disebut tuntas belajar apabila minimal $75 \%$ siswa di kelas tersebut telah mencapai ketuntasan belajar minimal 75.

Langkah-langkah analisis terdiri dari tiga alur kegiatan yang terjadi secara bersamaan yaitu: (1) reduksi data, (2) penyajian data, (3) penarikan kesimpulan.

\section{HASIL \\ Siklus I}

Pelaksanaan tindakan dilakukan berdasarkan rencana pelaksanaan pembelajaran yang sudah disusun pada tahap perencanaan. Siklus I pertemuan ke-1 dilaksanakan pada hari Senin, tanggal 20 Agustus 2018. Kegiatan pendahuluan diawali dengan salam pembuka, doa yang dipimpin salah satu siswa. Guru melakukan apersepsi dengan bertanya jawab tentang air. Selanjutnya guru menginformasikan materi yang akan dipelajari serta tujuan pembelajaran.

Pada tahap pertama guru memasang media gambar tentang berbagai permainan yang dapat menyehatkan, permainan tersebut meliputi jalan kaki, lompat tali, ular naga, tapak gunung, balap karung. Tahap kedua, guru meminta siswa untuk memperhatikan gambar pada media gambar yang sudah terpasang di papan tulis. Guru melakukan tanya jawab untuk menggali wawasan siswa. Siswa diperbolehkan mengeluarkan pendapatnya tentang gambar pada media. Tahap ketiga, guru menjelaskan tentang permainan menarik yang bisa dilakukan, dan hal-hal yang akan terjadi jika kekurangan atau kelebihan air. Tahap keempat, guru mengarahkan perhatian siswa pada media gambar kemudian meminta siswa untuk memikirkan katakata yang sesuai dengan setiap gambar. Tahap kelima, guru membagikan lembar tes individu kepada siswa. Guru menugaskan siswa untuk menjawab pertanyaan berkaitan dengan kosakata tentang memelihara kesehatan.

Pelaksanaan tindakan Siklus I Pertemuan ke-2 dilakukan berdasarkan rencana pelaksanaan pembelajaran yang sudah disusun pada tahap perencanaan. Siklus I pertemuan ke-2 dilaksanakan pada hari Selasa tanggal 21 Agustus 2018. Kegiatan pendahuluan diawali dengan salam pembuka, doa yang dipimpin salah satu siswa. Guru melakukan apersepsi dengan memberikan pertanyaan berkaitan dengan cara menjaga kesehatan. Selanjutnya guru menginformasikan materi yang akan dipelajari serta tujuan pembelajaran.

Pada tahap pertama guru memasang media gambar berkaitan dengan cara menjaga kesehatan. Tahap kedua, guru meminta siswa untuk memperhatikan gambar pada media peraga. Tahap ketiga, guru menjelaskan tentang cara menjaga kesehatan yang bisa dilakukan oleh setiap orang. Tahap keempat, guru mengarahkan perhatian siswa pada media gambar sambil mengajukan pertanyaan kepada siswa secara bergantian satu persatu. Tahap kelima, guru membagikan lembar tes individu kepada siswa.

Hasil Tahap Observasi aktivitas guru Siklus I pertemuan I dan II menggunakan lembar observasi guru dan diisi oleh observer yaitu guru kelas 1B. Aspek yang diamati dalam lembar observasi guru dengan melaksanakan pembelajaran dengan media gambar terdapat delapan aspek. Hasil rekapitulasi observasi aktivitas guru pada siklus I pertemuan I dan II menjelaskan bahwa telah terjadi peningkatan aktivitas guru dari pertemuan I ke pertemuan II sebesar $12.5 \%$. Rata-rata Siklus I sebesar $68,75 \%$, termasuk kategori cukup.

Penilaian observer dalam lembar observasi aktivitas siswa terdapat dua aspek. Rekapitulasi hasil aktivitas siswa pada siklus I pertemuan I dan II terdapat peningkatan aktivitas siswa dari pertemuan I ke pertemuan II siklus I. Pada pertemuan ke-1 terdapat 20 anak mengikuti pembelajaran dengan tertib dan meningkat pada pertemuan ke-2 menjadi 22 anak. Pada pertemuan ke-1 terdapat 23 siswa 
mengerjakan tugas dengan tertib dan meningkat pada perteuan ke-2 menjadi 25. Persentase keberhasilan pada pertemuan ke-1 sebesar $76,79 \%$ meningkat pada pertemuan ke-2 menjadi 83,93\%. Sehingga diperoleh rata-rata sebesar $80,93 \%$.

Rekapitulasi hasil tes individu Siklus I Pertemuan ke-I dan ke-II dapat dilihat pada tabel berikut:

Tabel 1 Rekapitulasi Tes Individu Siklus I Pertemuan I dan II

\begin{tabular}{|l|c|c|c|}
\hline \multicolumn{1}{|c|}{ Keterangan } & Pertemuan I & Pertemuan II & Rata-rata Siklus I \\
\hline Jumlah & 2180 & 2260 & 2220 \\
\hline Rata-rata & 78 & 81 & 79 \\
\hline Jumlah siswa tuntas & 17 & 21 & 19 \\
\hline Persentase siswa Tuntas & $61 \%$ & $75 \%$ & $68 \%$ \\
\hline Jumlah siswa belum tuntas & 11 & 7 & 9 \\
\hline Persentase siswa Tidak Tuntas & $39 \%$ & $25 \%$ & $32 \%$ \\
\hline
\end{tabular}

Berdasarkan tabel di atas diketahui bahwa jumlah hasil belajar siswa kelas $1 \mathrm{~A}$ pada siklus I pertemuan I sebesar 2180 dan meningkat menjadi 2260 pada pertemuan II sehingga diperoleh rata-rata sebesar 2220 . Nilai rata-rata hasil belajar siswa pada pertemuan I sebesar 78 dan meningkat menjadi 81 pada pertemuan II. Rata-rata nilai siswa pada Siklus I sebesar 79. Jumlah siswa yang tuntas pada pertemuan I sebesar $61 \%$ meningkat pada pertemuan II menjadi $75 \%$, dengan rata-rata sebesar $68 \%$.

Catatan lapangan yang diperoleh selama pelaksanaan : 1) Pada Siklus I pertemuan ke-1 guru menjelaskan terlalu cepat sehingga nilai siswa belum memuaskan karena belum mencapai ketuntasan klasikal. Gambar pada media gambar masih terlihat kurang jelas jika dilihat oleh siswa yang duduk di deretan belakang. Guru belum dapat menggunakan alokasi waktu dengan optimal. 2) Pada Siklus I pertemuan ke-2 Guru sudah dapat mengatur kecepatan bicara saat menerangkan, sehingga siswa lebih memahami penjelasan guru. Gambar pada media gambar juga lebih jelas terlihat dari bangku deretan belakang. Namun waktu yang digunakan masih belum optimal.

Refleksi Siklus I Guru perlu memperbaiki media gambar yang digunakan dalam pembelajaran supaya dapat terlihat jelas oleh siswa yang duduk pada bangku deretan belakang. Perbaikan pada media dapat dilakukan dengan mengurangi tampilan gambar atau dengan memperbesar gambar itu sendiri. Guru juga harus dapat menggunakan alokasi waktu yang tersedia dengan baik.

\section{Siklus II}

Pelaksanaan tindakan dilakukan berdasarkan rencana pelaksanaan pembelajaran yang sudah disusun pada tahap perencanaan. Siklus II pertemuan ke-1 dilaksanakan pada hari Kamis tanggal 23 Agustus 2018 membahas tema 2 subtema 1 pembelajaran ke-3. Kegiatan pendahuluan diawali dengan salam pembuka, doa yang dipimpin salah satu siswa. Guru melakukan apersepsi dengan memberikan pertanyaan berkaitan dengan pembelajaran sebelumnya. Guru menginformasikan materi yang akan dipelajari serta tujuan pembelajaran.

Pada tahap pertama guru memasang media gambar di papan tulis. Tahap kedua, guru meminta siswa untuk memperhatikan gambar pada media gambar. Tahap ketiga, guru menjelaskan tentang kegunaan air untuk kehidupan sehari-hari. Guru menugaskan siswa untuk mengamati gambar jenis-jenis olahraga yang ada di papan. Tahap keempat, guru mengarahkan perhatian siswa pada media gambar sambil mengajukan pertanyaan kepada siswa secara bergantian satu persatu. Tahap kelima, guru membagikan lembar tes individu kepada siswa. Selanjutnya bersama siswa membahas tes tersebut. Guru memberi penguatan tentang materi hari itu, sebelum menutup pertemuan.

Pelaksanaan tindakan dilakukan berdasarkan rencana pelaksanaan pembelajaran yang sudah disusun pada tahap perencanaan. Siklus II pertemuan ke-2 dilaksanakan pada hari Selasa, 28 Agustus 2018. Kegiatan pendahuluan diawali 
dengan salam pembuka, doa yang dipimpin salah satu siswa. Guru melakukan apersepsi dengan memberikan pertanyaan berkaitan dengan pembelajaran sebelumnya. Guru menginformasikan materi yang akan dipelajari serta tujuan pembelajaran.

Pada tahap pertama guru memasang media gambar tentang olahraga kegemaran. Tahap kedua, guru meminta siswa untuk memperhatikan gambar pada media gambar. Tahap ketiga, guru menjelaskan tentang olahraga apasaja yang bisa dijadikan kegemaran. Tahap keempat, guru mengarahkan perhatian siswa pada media gambar sambil mengajukan pertanyaan kepada siswa secara bergantian satu persatu. Tahap kelima, guru membagikan lembar tes individu kepada siswa. Selanjutnya bersama siswa membahas tes tersebut. Guru memberi penguatan tentang materi hari itu, sebelum menutup pertemuan.

Hasil Tahap Observasi aktivitas guru menggunakan lembar observasi guru dan diisi oleh observer. Aspek yang diamati dalam lembar observasi guru dengan melaksanakan pembelajaran dengan media gambar terdapat delapan aspek. Semua aspek dalam lembar observasi telah muncul. Rekapitulasi hasil observasi guru pada Siklus II pertemuan I dan II

menjelaskan bahwa pada siklus II pertemuan I terdapat tujuh aspek yang telah muncul dan meningkat pada pertemuan II menjadi delapan aspek. Persentase keberhasilan pada siklus II mencapai rata-rata sebesar $93,75 \%$ atau mencapai kriteria sangat baik.

Penilaian observer dalam lembar observasi aktivitas siswa terdapat dua aspek. Rekapitulasi hasil aktivitas siswa Siklus II pertemuan I dan II terdapat 24 anak yang dapat mengikuti pembelajaran dengan tertib pada Siklus II pertemuan I dan meningkat pada pertemuan II menjadi 27 anak. Siswa yang mengerjakan tugas dengan tertib pada pertemuan I ada 25 anak dan menjadi maksimal pada pertemuan II yaitu menjadi 28 anak. Perolehan rata-rata hasil observasi aktivitas siswa pada siklus II sebesar $92,86 \%$ atau mencapai kategori sangat baik.

Penilaian siswa diperoleh dari hasil tes individu yang diberikan setiap akhir pembelajaran. Rekapitulasi hasil tes individu Siklus II pertemuan I dan II dapat dilihat pada tabel berikut::

Tabel 2 Rekapitulasi Hasil Tes Individu Siklus II Pertemuan I dan II

\begin{tabular}{|l|c|c|c|}
\hline Keterangan & Pertemuan I & Pertemuan II & Rata-rata Siklus II \\
\hline Jumlah & 2330 & 2390 & 2360 \\
\hline Rata-rata & 83 & 85 & 84 \\
\hline Jumlah siswa tuntas & 23 & 26 & 25 \\
\hline Persentase siswa Tuntas & $82 \%$ & $93 \%$ & $88 \%$ \\
\hline Jumlah siswa belum tuntas & 5 & 2 & 4 \\
\hline Persentase siswa Tidak Tuntas & $18 \%$ & $7 \%$ & $13 \%$ \\
\hline
\end{tabular}

Tabel di atas menjelaskan bahwa jumlah hasil belajar siswa kelas $1 \mathrm{~A}$ pada siklus II pertemuan I adalah 2330 dan meningkat menjadi 2390 pada pertemuan II, sehingga diperoleh rata-rata siklus II sebesar 2360. Jumlah siswa tuntas pada pertemuan I sebanyak 23 siswa dan meningkat menjadi 26 siswa pada pertemuan II, atau telah tercapai ketuntasan klasikal sebesar $88 \%$

Catatan selama pelaksanaan yaitu : 1) Pada Siklus II pertemuan ke-1 siswa menyukai media gambar. Berkat bimbingan dan motivasi dari guru siswa dapat memahami materi pembelajaran dengan baik. Untuk pertemuan berikutnya guru perlu mengupayakan penggunaan waktu supaya lebih optimal. 2) Pada Siklus II pertemuan ke-2 guru telah dapat menggunakan alokasi waktu yang tersedia secara optimal. Media Gambar yang dibuat guru lebih menarik dari sebelumnya.

Refleksi Pada Siklus II, siswa lebih mudah memahami materi pembelajaran. Berkat bimbingan dan motivasi dari guru siswa dapat menyelesaikan tugas individu 
tepat pada waktunya. Guru telah dapat menggunakan alokasi waktu yang tersedia secara optimal. Media Gambar yang dibuat guru lebih menarik dari sebelumnya.

\section{PEMBAHASAN}

Tahap ini membahas tentang (1) keterlaksanaan pembelajaran dengan media gambar (2) hasil belajar mengenal mengenal kosakata tentang cara memelihara kesehatan setelah dilaksanakan pembelajaran dengan media gambar.

\section{Keterlaksanaan Pembelajaran dengan Media Gambar}

Keterlaksanaan pembelajaran dengan menggunaan media gambar dalam penelitian ini ditunjukkan dengan (1) hasil observasi aktivitas guru dalam melaksanakan pembelajaran sesuai langkah-langkah pembelajaran dengan media gambar (2) hasil observasi aktivitas siswa dalam mengikuti pembelajaran dan (3) hasil catatan lapangan setelah dilaksanakan pembelajaran dengan media gambar. Dari siklus I dan siklus II diperoleh hasil observasi aktivitas guru pada siklus I pertemuan I mendapatkan persentase $62,5 \% \%$ dalam kriteria cukup, pertemuan II mendapatkan persentase $75 \%$ dalam kriteria baik, sehingga terjadi peningkatan $12.5 \%$, rata-rata keberhasilan guru dalam mengelola pembelajaran menggunakan media gambar adalah $68,75 \%$. Pada siklus II pertemuan I mendapatkan persentase $87,5 \%$ dalam kriteria sangat baik dan pertemuan II mendapatkan persentase $100 \%$ dalam kriteria sangat baik, ada peningkatan 12,5\%. Rata-rata siklus II diperoleh keberhasilan sebesar $93,75 \%$

Sedangkan hasil observasi aktivitas siswa pada siklus I pertemuan I mendapatkan persentase $76,79 \%$ dalam kriteria baik, pertemuan II mendapatkan persentase $83,93 \%$ dalam kriteria baik, ada peningkatan $7,14 \%$. Siklus II pertemuan I mendapatkan persentase $87,50 \%$ dan pertemuan ke-2 mendapatkan persentase $88,46 \%$ terdapat kenaikan sebesar $10,26 \%$ dengan rata-rata sebesar $98,21 \%$, rata-rata siklus II diperoleh 92,86\% termasuk kategori sangat baik.

Keterlaksanaan pembelajaran dalam penelitian ini ditunjukkan oleh hasil observasi aktivitas guru sebagai data wajib dan hasil observasi aktivitas siswa sebagai data pendukung serta dilengkapi dengan catatan lapangan sebagai data penunjang.

Data keterlaksanaan pelaksanaan pembelajaran yang dihasilkan dalam penelitian ini selalu menunjukkan peningkatan hasil dan kriteria yang konsisten mulai dari pertemuan I ke pertemuan II pada siklus I dan pertemuan I ke pertemuan II pada siklus II. Berdasarkan indikator keberhasilan yang sudah ditetapkan di bab III dapat diambil kesimpulan bahwa pelaksanaan pembelajaran mengenal mengenal kosakata tentang cara memelihara kesehatan setelah dilaksanakan pembelajaran dengan media gambar terbukti efektif.

\section{Hasil belajar siswa mengenal mengenal kosakata tentang cara memelihara kesehatan.}

Hasil belajar siswa dalam penelitian ini ditunjukkan dengan hasil nilai tes individu. Nilai Tes individu siklus I pertemuan I mendapatkan rata-rata sebesar 78 dan meningkat menjadi 81 pada pertemuan II. Ketuntasan belajar yang diperoleh pada Siklus I pertemuan I sebesar $61 \%$ dan meningkat menjadi $75 \%$ pada pertemuan II. Rata-rata ketuntasan belajar siswa pada siklus I sebesar $68 \%$. Ketuntasan tersebut belum mencapai KKM yang dipersyaratkan yaitu sebesar $75 \%$.

Hasil belajar siswa Siklus II pertemuan I diperolah rata-rata sebesar 83 dan meningkat menjadi 85 pada pertemuan II sehingga diperoleh rata-rata untuk siklus II sebesar 84. Ketuntasan klasikal pada Siklus II pertemuan I sebesar $82 \%$ dan meningkat menjadi $93 \%$ sehingga diperoleh rata-rata sebesar $88 \%$ dalam kriteria baik dan sudah mencapai ketuntasan klasikal.

Kenaikan tersebut menunjukkan bukti bahwa media gambar dapat membantu siswa mencapai ketuntasan belajar klasikal, yang berarti adanya peningkatan dalam hal pemahaman dan hasil belajar siswa. Hal tersebut sejalan dengan pendapat Arsyad 
Vol. 2 No. 4, Oktober 2018;

A. (2002) bahwa salah satu kelebihan media gambar adalah siswa akan lebih mudah dalam memahami materi, sehingga hasil belajar dapat meningkat.

Hasil belajar siswa mengenal kosakata tentang cara memelihara kesehatan setelah dilaksanakan pembelajaran dengan media gambar teruji dan terbukti meningkat, dengan meningkatnya hasil belajar siswa secara konsisten. Pada saat proses membangun pemahaman siswa dalam pembelajaran ini melalui langkahlangkah pelaksanaan pembelajaran menggunakan media gambar membutuhkan keahlian guru dalam memilihkan gambar-gambar yang menarik untuk dijadikan media.

Berdasarkan pembahasan ini sesuai dengan indikator keberhasilan yang sudah ditetapkan dapat diambil kesimpulan bahwa pembelajaran dengan menggunakan media gambar dapat meningkatkan hasil belajar mengenal kosakata tentang cara memelihara kesehatan bagi siswa kelas 1A SDN Blitar.

Kendala yang muncul dari guru yaitu belum dapat menggunakan waktu yang tersedia secara optimal. Selain itu dalam membuat media gambar diperlukan keahlian guru dalam memilih dan mengkombinasi gambar supaya menjadi media yang menarik.

Selama pembelajaran guru harus selalu memberikan motivasi, bimbingan, perhatian, dan penguatan kepada siswa. Hal ini bertujuan agar siswa lebih aktif dan tertib dalam mengerjakan tugasnya, sehingga siswa bisa lebih percaya diri dengan pekerjaannya sendiri.

\section{KESIMPULAN}

Berdasarkan pembahasan pada bab IV maka hasil penelitian dapat disimpulkan: 1) Pelaksanaan pembelajaran dengan menggunakan media gambar pada siswa kelas 1A SDN Blitar dengan materi mengenal kosakata tentang cara memelihara kesehatan telah teruji dan efektif. Terbukti dari data keterlaksanaan pelaksanaan pembelajaran yang dihasilkan dalam penelitian ini selalu menunjukkan hasil peningkatan persentase dan kriteria yang selalu konsisten dari pertemuan I dan II siklus I dan pertemuan I dan II siklus II. 2) Peningkatan hasil belajar siswa setelah dilaksanakan pembelajaran dengan menggunakan media gambar dapat dilihat setiap akhir pertemuan. Peningkatan hasil belajar tersebut dibuktikan dengan meningkatnya hasil tes individu dari siklus I dengan rata-rata sebesar 79 menjadi 84 pada siklus II. Ketuntasan belajar siswa meningkat dari siklus I sebesar $68 \%$ meningkat menjadi $88 \%$ pada siklus II. Sehingga ditarik simpulan bahwa pembelajaran dengan menggunakan media gambar dapat meningkatkan hasil belajar mengenal mengenal kosakata tentang cara memelihara kesehatan bagi siswa kelas 1A SDN Blitar Kecamatan Sukorejo Kota Blitar.

\section{SARAN}

Bagi guru, diharapkan guru dapat mempersiapkan media gambar yang menarik bagi siswa supaya siswa lebih termotivasi untuk memperhatikan pembelajaran. Bagi siswa, diharapkan siswa lebih aktif dalam mengikuti pembelajaran. Bagi Sekolah, diharapkan sekolah bisa mendukung penelitiian guru-guru dengan menyediakan sarana prasarana pembelajaran yang memadai, baik berupa buku referensi ataupu fasilitas yang lain.

\section{DAFTAR RUJUKAN}

Arsyad, A. 2002. Media Pembelajaran. Jakarta : PT. Raja Grafindo Persada.

Basuki., \& Farida. 2001. Media Pengajaran. Bandung : CV Maulana.

Bundu, Patta. 2005. Penilaian Keterampilan Proses dan Sikap IImiah Dalam Pembelajaran PKn SD. Jakarta: Departemen Pendidikan Nasional Direktorat Jenderal Pendidikan Tinggi.

Dimyati., \& Mujiono. 2002. Belajar dan Pembelajaran. Jakarta: Rineka Cipta.

Sanjaya, W. 2011. Strategi Pembelajaran Berorientasi Standar Proses Pendidikan, Jakarta: Kencana Prenada Media.

Undang-undang No 20 Tahun 2003 tentang Sistem Pendidika Nasional. 